\title{
DISKRIMINASI GENDER PEREMPUAN PAPUA DALAM NOVEL ISINGA KARYA DOROTHEA ROSA HERLIANY
}

\author{
Hasrul Rahman \\ Alumni Pascasarjana Universitas Sebelas Maret \\ Email: rahmanhasrul12@gmail.com
}

\begin{abstract}
This study describes a novel Isinga gender discrimination in the work of Dorothea Rosa Herliany . The data collection was done by engineering literature. This study used descriptive qualitative method. The data source is a novel research Isinga work of Dorothea Rosa Herliany. The method used is content analysis. The results of this study resulted in the following points. First, it shows the existence of gender discrimination that includes a variety of things, both physical and sexual. Secondly, the characteristics of the men in the novel Isinga work of Dorothea Rosa Herliany.
\end{abstract}

Key Word: novel, gender discrimination, women's Papua

\begin{abstract}
ABSTRAK
Penelitian ini mendeskripsikan diskriminasi gender dalam novel Isinga karya Dorothea Rosa Herliany. Pengumpulan data dilakukan dengan cara teknik kepustakaan. Penelitian ini menggunakan metode deskriptif kualitatif. Sumber data penelitian adalah novel Isinga karya Dorothea Rosa Herliany. Metode yang digunakan adalah content analysis. Hasil penelitian ini menghasilkan hal-hal berikut. Pertama, menunjukkan adanya diskriminasi gender yang mencakup berbagai hal, baik fisik maupun seksual. Kedua, karakteristik kaum laki-laki dalam novel Isinga karya Dorothea Rosa Herliany.
\end{abstract}

Kata kunci: novel, diskriminasi gender, perempuan Papua

\section{PENDAHULUAN}

Berbicara gender berarti secara tidak

langsung akan membuka persoalan seputar ketidakadilan. Berkembangnya zaman dan ilmu teknologi tidak lantas menyelesaikan masalah terhadap diskriminasi gender. Masih banyak persoalan gender yang berkembang di masyarakat, terutama diskriminasi yang lahir sebagai sebuah budaya. Dengan masih adanya diskriminasi gender, diperlukan pemahaman secara meluas terutama masyarakat yang tinggal di daerah pelosok. Kurangnya pemahaman dan faktor budaya yang ada bisa disebut sebagai akar permasalahannya. Dilihat dari segi budaya, persoalan gender memang tidak seperti 
zaman dahulu. Terciptanya sebuah karya sastra membuat permasalahan yang timbul di dalam lingkungan masyarakat akan banyak membantu kaum perempuan yang selama ini termarginalkan, terutama di daerah pelosok. Untuk memahami permasalahan seputar gender, diperlukan kajian yang sesuai dengan pesoalan yang melatarbelakanginya. Menurut Fakih (2013: 12) perbedaan gender sesungguhnya tidaklah menjadi masalah sepanjang tidak melahirkan ketidakadilan gender (gender inequalities).

Setiap karya sastra yang lahir pastinya memiliki tujuan tertentu untuk mengangkat problematik kehidupan sosial yang terjadi. Terutama masalah-masalah sosial yang berkembang di masyarakat. Salah satu karya sastra yang menampilkan problematika sosial dengan mengangkat permasalahan perempuan sebagai tokoh utamanya terdapat dalam novel Isinga (2015) karya Dorothea Rosa Herliany. Novel ini mengandung nilai kearifan lokal yang masih sangat kental. Disamping nilai budaya yang ditonjolkan, ada persoalan diskriminasi gender yang perlu diungkap.

Novel ini menggambarkan tokoh perempuan yang terbelenggu oleh aturan adat. Dalam novel ini persoalan yang timbul bermula dari kepercayaan animisme yang berkembang dalam masyarakat adat, sehingga diskriminasi terhadap kaum perempuan tak terelakan. Latar tempat novel ini diambil dari daerah pedalaman Papua. Dilihat dari segi isinya, di sini pengarang ingin mengangkat derajat perempuan Papua yang selalu tersandra oleh hukum adat yang berlaku. Kelemahan perempuan menjadi sasaran empuk bagi kaum laki-laki yang terus menempatkannya dibelakang. Fakih, (2012: 78- 79) mengatakan bahwa feminisme bukan merupakan upaya pemberontakan terhadap laki-laki, upaya melawan pranata sosial seperti institusi rumah tangga dan perkawinan, upaya perempuan untuk mengingkari kodratnya, tetapi upaya untuk mengakhiri penindasan dan eksploitasi perempuan. 
Konflik yang terjadi dalam novel tersebut memunculkan pemahaman tentang aspek permasalahannya yang perlu dikaji, sehingga untuk memahami persoalan tersebut digunakan tinjauan feminis sosialis. Menurut Endaswara (2008: 147) analisis dalam kajian feminis hendaknya mampu mengungkap aspek-aspek ketertindasan wanita atas diri pria. Dari permasalahan tersebut, penelitian ini mengangkat beberapa masalah yakni (1) bagaimanakah diskriminasi gender dalam novel Isinga? (2) bagaimanakah karakteristik laki-laki dalam novel Isinga?

\section{METODE PENELITIAN}

Metode yang digunakan dalampenelitian ini adalah metode kualitatifdeskriptif. Metode kualitatif adalah prosedur penelitian yang menghasilkan data deskripsi berupa kata-kata tertulis atau lisan dari orang-orang dan perilaku yang dapat diamati (Moleong, 2007: 3). Teknik pengumpulan data menggunakan content analysis. Adapun aspek penting dari content analysis adalah bagaimana hasil analisis dapat diimplikasikan kepada siapa saja (Waluyo, 2011:65).

Metode yang digunakan adalah analisis dokumen.Teknik validitas data dengan trianggulasi data. Peneliti menggunakan beberapa data untuk mengumpulkan data yang sama. Teknik analisis data yang digunakan dalam penelitian ini adalah teknik analisis interaktif, yang terdiri atas reduksi data, sajian data, dan penarikan simpulan atau verifikasi. Aktivitas ketiga komponen tersebut dilakukan secara interaktif dengan proses pengumpulan data (Miles dan Huberman, 2007: 20).

\section{HASIL PENELITIAN DAN}

\section{PEMBAHASAN}

Hasil penelitian ini mendekripsikan diskriminasi gender yang dilakukan salah satu suku yang terdapat di tanah Papua. Dorothea Rosa sebagai penulis ingin menyampaikan kegundahan hatinya dalam menyikapi fenomena yang sedang terjadi di 
sana. Dalam novel Isinga, diskriminasi gender yang terjadi disebabkan adanya aturan adat yang mengatur ruang gerak perempuan dalam menjalani kehidupan.

\section{Diskriminasi Gender dalam Novel Isinga}

Diskriminasi gender yang terdapat dalam novel Isinga merupakan wujud dari sebuah budaya yang melekat di dalam masyarakat adat Papua. Ketimpangan gender yang terdapat dalam novel Isinga membuat perempuan Papua selalu dibatasi ruang geraknya dalam segala bidang. Dalam novel

Isinga, tokoh perempuannya digambarkan dalam diri Irewa sebagai perempuan yang kuat. Ia merupakan wujud perempuan Papua yang patuh terhadap budayanya yang menjadi dasar kehidupan. Sopan santunya terhadap laki-laki menjadi simbol keperibadiannya yang diajarkan oleh kedua orang tuanya.

Sikapnya nampak pada kutipan berikut.

Di Aitubu laki-laki dan perempuan tidak saling memberi salam. Bila berpapasan, perempuan biasanya menunduk lalu menunggu sampailakilaki itu lewat. Jarang laki-laki dan perempuan bercakap-cakap di kebun. Apalagi di tengah jalan (Isinga, hlm 27)
Sikapnya yang tunduk terhadap budaya yang ada, membuat Irewa menjadi incaran banyak pria, salah satunya Malom. Bermula dari ketertarikan Malom terhadap Irewa, pertikaian dan diskriminasi itu terjadi. Malom merupakan laki-laki yang tinggal di kampung yang mempunyai riwayat pertikaian dengan kampung Irewa. Suatu malam ketika Irewa sedang melakukan upacara menstruasi, ia diculik oleh Malom. Padahal saat itu Irewa sudah dilamar oleh Meage dan sebentar lagi akan ada upacara pernikahan untuknya. Upacara menstruasi merupakan ritual bagi kaum perempuan yang sudah siap untuk menikah. Akan tetapi takdir berkata lain, Irewa dipaksa menikah dengan Malom. Sesaat setelah menikah sifat aslinya mulai nampak. Perbedaan pandangan dalam hal budaya juga mulai nampak. Berikut kutipan mengenai pandangan budaya yang ada.

"Semua perempuan di Pegunungan Megafu punya tugas menyediakan makan bagi keluarga masing-masing. Dalam keadaan yang bagaimanapun, tugas itu 
harus dilakukan. Tak pernah ada laki-laki Megafu menyiapkan makan untuk keluarga (Isinga, hlm 62).

Kutipan di atas mendeskripsikan kehidupan perempuan Papua yang jauh dari kata bahagia. Laki-laki di pegunungan Megafu tidak ada yang mau bekerja untuk membantu isteri. Semua kebutuhan keluarga menjadi kewajiban isteri untuk mememenuhinya, disamping merawat anak.

Laki-laki Hobone selalu mengandalkan isterinya untuk berbagai hal. Menurut pandangan laki-laki di sana, mendapatkan seorang isteri itu tidak mudah. Harus memiliki hewan piaraan yang banyak. Kewajiban seorang suami ketika mau menikah wajib membeli isterinya dengan mahar yang sangat mahal. Dampaknya para suami di sana memperlakukan isterinya sesuka hati.

Sistem kehidupan masayarakat di Pegunungan Megafu jauh berbeda dengan masyarakat lainnya. Laki-laki di sana lebih mementingkan kebahagiaan dirinya dari pada keluarga. Para perempuan di desa tersebut tidak ada yang berani melawan ketidakadilan itu. Mereka takut terkena kutukan jika berani melawan atau membantah perintah laki-laki. Semua pekerjaan untuk memenuhi kebutuhan keluarga dilakukan oleh isteri terkecuali berburu.

"Mama Fos Malom memberi tahu, perempun Hobone menangkap ikan dengan menggunakan jaring. Jalanya harus dibuat sendiri dan kalau rusak haru diperbaiki sendiri"'(Isinga, hlm 61)

"Kalau pagi Irewa mendayung perahu, pergi ke tengah danau mencari ikan. Setelah mendapat ikan, ia pulang. Ikan dikeringkan. Nanti akan dimasaka untuknya dan Malom. setelah itu Irewa pergi ke kebun yang letaknya jauh. Tanah dibersihkan dari alang-alang dan segala tanaman pengganggu. Jika ada ulat atau serangga dibunag. Ia lalu mememtik sayur untuk dibawa pulang (Isinga, hlm 64).

Pada kutipan tersebut mempertegas adanya diskriminasi gender yang dilakukan oleh kaum pria di sana. Laki-laki di Pegunungan Megafu memiliki kekuasaan yang sangat kuat, mereka menganggap perempuan hanya tempat untuk menghasilkan anak. Kehidupan seperti itu merupakan wujud dari kebiasaan yang turun temurun mereka lakukan, sehingga menjadi sebuah kebudayaan yang salah. Pemikiran 
kaum laki-laki di Pegunungan Megafu masih sangat tradisional, sehingga banyak kaum perempuan yang termarginalkan dalam segala aspek.

Masyarakat di Pegunungan Megafu memiliki pedoman sendiri untuk memposisikan perempuan yang dianggapnya baik. Untuk dianggap baik, para perempuan di sana tidak cukup hanya mematuhi perintah suami menjalankan tugas sebagai pencari nafkah dan merawat anak semata. Akan tetapi perempuan di sana harus mampu menerapkan norma adat yang ada.

"Perempuan yang baik itu mesti pendiam. Tidak pernah mengeluh. Tidak pernah protes. Tidak pernah membantah. Tidak pernah bersedih. Tidak pernah berbicara kasar. Tidak pernah menyakiti hati orang lain. Tidak suka bertengkar. Tidak suka marah. Tidak pernah mendendam. Tidak pernah punya perasaan dengki pada orang lain. Senag membantu orang lain. Tidak mengeluh kalau kesulitan. Penurut. Bersuara lembut. Tidak pernah berkelahi. Tidak suka mencari masalah. Tidak senang menyalahkan orang lain. Tidak pernah menjengkelkan orang lain. Tidak pelit. Tidak serakah. Tidak melakukan hal buruk, hal-hal tidak terpuji. Sabar. Tabah. Hidup yang baik.Bekerjalah dengan giat. Memiliki pengetahuan. Bisa menunjukkan keterampilan tangan kiri. Bisa menunjukkan keterampilan tangan kanan. Selalu menyiapkan maakanan untuk keluarga. menghidangkan hasil kebun dengan setulus hati. Perempuan harus bisa mengurus suami dengan baik. Budi bahasa baik. Tutur kata manis. Perempuan yang berbicara tak hentihenti seperti burung yoye dan kasengge (jenis burung yang suka berkicau) (Isinga hlm 66).

Perempuan di Pegenunungan Megafu dituntut untuk tidak pernah mengeluh. Walaupun pekerjaannya sangat banyak, perempuan di sana harus tetap menjalankan semua kewajibannya sebagai seorang isteri. Bagi perempuan Megafu menjadi perempuan yang baik itu sangat sulit disamping harus memenuhi kebutuhan keluarga mereka juga dituntut harus ramah terhadap suaminya. Kepercayaan terhadap hal-hal yang besifat animisme menjadikan perempuan di sana lemah dalam segala hal.

Diskriminasi yang timbul terhadap perempuan bukan saja dalam hal kebutuhan lahirnya, akan tetapi dalam hal kebutuhan batinnya juga. Kekerasan yang Irewa alami sudah menjadi hal yang lumrah, bahkan bukan hanya dirinya sendirinya yang mengalami hal tersebut. Perempuan di 
Pegunungan Megafu rata-rata mengalami semua diskriminasi tersebut.

"Irewa memaksakan diri melayani permintaan Malom. Tak senang. Tegang. Kelaminnya terasa nyeri. Sakit. Irewa harus menghadapi apa saja yang terjadi atas dirinya. Begitulah juga yang dialami semua perempuan lain di bawah pegunungan Megafu. mereka ratarata mengalami hal sama. Harus terus-menerus melayani suami. Merawat anak jika nanti sudah lahir. Dan mengurus semua kebutuhan keluarga. Tak ada yang mengeluh" (Isinga, hlm 70).

"Begitulah hari-hari Irewa. Seperti sudah ditetapkan bahwa ia harus terus menerus bekerja. Juga harus terus menerus beranak. Setelah anaknya yang kedua itu, Irewa hamil lagi. Tapi karena pekerjaan yang berat dan makan kurang, kembali Irewa keguguran. Tak lama, Malom mengajak bersetubuh lagi. Lalu Irewa hamil lagi” (Isinga, hlm 73).

Laki-laki di Pegunungan Megafu memiliki kemauan yang kuat untuk memiliki banyak anak terutama anak laki-laki. Makin banyak anak laki-laki makin berharga dan bermartabat. Kepercayaan tersebut yang membuat para perempuan di sana dipaksa untuk mengandung terus menerus. Akibatnya banyak perempuan yang meninggal dunia karena lemas. Selain itu banyak juga perempuan di Pegunungan Megafu yang lebih memilih bunuh diri daripada harus menuruti semua keinginan suaminya.

"Kalau ada seorang suami memperlakukan isteri dengan tidak baik, ada dua cara bagi perempuan Megafu untuk bisa lepas dari suaminya itu. Pertama bunuh diri dengan terjun ke sungai besar dan deras. Ini banyak yang sudah melakukannya. Kedua, menunggu kalau ada laki-laki lain yang menyukainya. Tak bisa kalau keinginan datang dari perempuan" (Isinga, hlm 74).

Kejadian bunuh diri lebih sering terjadi di Pegunungan Megafu dari pada kejadian lainnya. Seperti halnya menunggu laki-laki lain untuk menebusnya, sebab para laki-laki di sana tidak ingin mencari musuh dengan cara merebut isteri orang. Akan tetapi perempuan di pegunungan Megafu tidak pernah memikirkan jalan berpisah dari suaminya.

\section{Karakteristik Laki-Laki dalam Novel Isinga}

Dalam novel Isinga, tokoh laki-laki yang digambarkan dalam diri Malom merupakan karakterisitik seorang laki-laki yang memiliki kekuasaan penuh atas isterinya. Bagi 
masyarakat di Pegunungan Megafu perempuan diibaratkan barang mewah yang memiliki harga ekonomis yang tinggi, sehingga laki-laki di sana melakukan tindakan semena-mena terhadap perempuan.

"Mas kawin tak ubahnya tanda bahwa perempuan sudah dibeli. Karena sudah dibeli, laki-laki bisa melakukan apa saja terhadap perempuan" (Isinga, hlm 140).

Pandangan kaum laki-laki terhadap perempuan dalam menyikapi budaya yang ada sudah sangat keliru. Diskriminasi yang terjadi terhadap kaum perempuan dianggap sebagai budaya yang wajib diikuti. Berbagai persolan yang berkembang dalam lingkup masyarakat adat di Pegunungan Megafu hanya berlandaskan budaya. Akibat kesalahan pandangan tersebut, perempuan menjadi korban para laki-laki dalam memperlakukan perempuan. Tindakan lakilaki di Pegunungan Megafu yang semenamena tidak lantas membuat perempuan dapat bangkit untuk melawan. Bagi Irewa, itu semua sudah menjadi kodratnya sebagai seorang perempuan yang taat akan aturan adat yang berlaku. Pandangan Irewa dan perempuan Megafu, melawan merupakan hal yang harus dihindari. Bukan saja karena takut dipukul, tetapi juga takut akan kutukan dan bencana jika berani melawan suaminya.

Perubahan zaman tidak membuat para laki-laki Megafu belajar dari dunia luar. Banyaknya penduduk dari luar Papua yang datang untuk mencari nafkah malah memberi angin segar bagi penduduk pribumi untuk menjual tanahnya. Laki-laki di Megafu banyak yang melanggar adat dengan menjual tanahnya untuk berfoya-foya. Padahal masyarakat di sana paling takut dengan sangsi adat dan berupa kutukan dari alam.

"Irewa tahu, Malom pergi ke "kota" distrik Yar hanya untuk menghabiskan uang saja. Bersenag-senang, minum-minuman keras dan pergi dengan para perempuan. Baik perempuan muda Papua atau perempuan Jawa pelacur" (Isinga, hlm 152).

Banyak laki-laki Papua yang terjebak di dalam dunia hitam, terutama minum minuman keras. Sudah bukan rahasia lagi, jika minuman beralkohol menjadi musuh nomer satu di Papua. Dalam hal kehidupan 
seksualnya, masyarakat di sana memiliki pandangan tersendiri dalam memiliki anak. Rata-rata mereka mempunyai banyak anak. Seperti halnya Malom yang kehidupannya dipenuhi dengan sifat yang emosional dan tidak mempunyai rasa empati terhadap isterinya, sehingga banyak perempuan di sana merasa tersiksa. Bagi masyarakat di Megafu mendapatkan anak sebanyak-banyaknya adalah prioritas utama seperti pohon bambu yang terus tumbuh.

"Malom memang tidak pernah berhenti meminta Irewa punya anak. Ia bicara tentang bambu. Pohon bambu memang sering dibicarakan oleh orangorang di bawah pegunungan Megafu kalau mereka membicarkan tentang anak. Bambu adalah lambang banyaknya keturunan. Bambu bisa tumbuh dengan baik dimana saja. Setelah tumbuh, mudah beranak pinak. Jumlahnya banyak sekali. Begitulah yang diharapkan masyarakat. Agar setiap perempuan punya banyak anak seperti pohon bambu” (Isinga, hlm 143)

\section{SIMPULAN}

Berdasarkan hasil penelitian dan pembahasan, dapat disimpulkan dua hal sebagai berikut. (1) Deskriminasi gender yang terdapat dalam novel Isinga adalah kekerasan fisik terhadap perempuan dan terbelenggu oleh adat yang mengikat. (2) Laki-laki di pegunungan
Megafu lebih tidak menghormati istri dari pada di kampuang halaman Irewa. Hal ini juga dipengaruhi oleh hukum adat yang tidak mewajibkan laki-laki mencari nafkah.

\section{DAFTAR PUSTAKA}

Endraswara, Suwardi. 2008. Metodologi Penelitian Sastra (Epistimologi, Model, Teori, dan Aplikasi). Yogyakarta: MedPress.

Fakih, Mansour. 2013. Analisis Gender dan Transformasi Sosial. Yogyakarta: Pustaka Pelajar Offest.

Herliany, Dorothea Rosa. 2015. Isinga. Jakarta: Gramedia.

Miles, Matthew B. Dan A Michael Huberman. 2007. Analisis Data Kualitatif. Jakarta: Universitas Indonesia Press.

Moleong, Lexy J. 2007. Metode Penelitian Kualitatif. Bandung: Remaja Rosdakarya.

Waluyo, Herman J. 2011. Pengkajian dan Apresiasi Prosa Fiksi. Surakarta: Sebelas Maret University Press. 